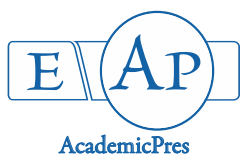

Singh Randhawa F and Kaur A (2021)

Notulae Scientia Biologicae

Volume 13, Issue 2, Article number 10874

DOI: $10.15835 / \mathrm{nsb} 13210874$

Research Article

\title{
Standardization of time of budding and sweet orange cultivars on Carrizo rootstock
}

\author{
Fatehdeep SINGH RANDHAWA, Amarjeet KAUR*
}

\author{
Khalsa College, Department of Horticulture, Amritsar-143001,Punjab, India; fatehrandhawa95@gmail.com;
}

dr.amarjitkaur30@gmail.com ("correspondingauthor)

\begin{abstract}
In sexual propagation of citrus long juvenility, genetic impurity and self incompatibility are the major problems. Hence the use of suitable rootstock is a pre-requisite in citrus propagation. Now a days, the cultivation of sweet orange is boosting up among citrus cultivation. Due to this, there is a great need for the evaluation of sweet orange cultivars onto an appropriate rootstock. A research trial was carried out in consideration with 'Blood Red', 'Jaffa' and 'Valencia Late' sweet orange cultivars T-budded on Carrizo rootstock at five different intervals of first week of July, August, September, October and February. The treatments were replicated thrice and statistically arranged in factorial randomized complete block design. As a result of the study significant variations were noticed in the performance of cultivars under study at various budding intervals. Out of the sweet orange cultivars 'Blood Red' was the first to initiate sprouting in 28.30 days with healing of bud union in 31.39 days, maximum survival (89.40\%), plant height $(22.93 \mathrm{~cm})$, number of branches buddling ${ }^{-1}(1.14)$, leaf total nitrogen (1.89\%), phosphorus (0.07\%) and potassium (1.26\%). Among budding intervals, the plants budded on the first week of September were the first to sprout in 26.46 days achieving maximum $(23.04 \mathrm{~cm})$ plant height, branches buddling ${ }^{-1}(1.15)$ root formation of $\left(5.98 \mathrm{~cm}^{3}\right)$ volume and survival percentage (91.99). Commercially, 'Blood Red' sweet orange cultivar budded in the first week of September can be cultivated for superior progeny.
\end{abstract}

Keywords: buddling; 'Blood Red'; Carrizo; cultivars; sprouting; survival; sweet orange

\section{Introduction}

Citrus cultivation is the most leading of all the fruit crops in tropics and sub-tropics of the world. It is placed under the family Rutaceae and is the largest group consisting of fruits formed of many segments with numerous juicy sacs. Pomologically the fruit of citrus is hesperidium. Although itis a sour fruit but is richly packed with various nutrients especially folic acid, vitamin C, flavonoids, dietary fibers, calcium, potassium and magnesium. Citrus is considered as a boon for the cancer patients due to the presence of chemo-preventive agents in it. They are also very helpful in reducing the constipation, diarrhea and many chronic diseases like arthritis, obesity and coronary heart diseases. Consumption of foods rich in vitamin C improves body immunity against infectious agents and scavenging harmful, pro-inflammatory free radicals from blood. Sweet orange contains a variety of phytochemicals like hesperidin and naringin which has a bio-active effect on human health as an antioxidant, free radical scavenger and immune system modulator (Milind and Chaturvedi, 2012).

Received: 29 Dec 2020. Received in revised form: 23 Apr 2021. Accepted: 07 Jun 2021. Published online: 11 Jun 2021.

From Volume 13, Issue 1, 2021, Notulae Scientia Biologicae journal uses article numbers in place of the traditional method of continuous pagination through the volume. The journal will continue to appear quarterly, as before, with four annual numbers. 
It contains low calories but rich in pectin which is considered as a bulk laxative, protects the mucous membrane from exposure to toxic substances as well as by binding to cancer causing chemicals. The plants propagated through seeds are generally self incompatible and genetically impure. Due to these problems, suitable scion and rootstock is necessary for budding sweet orange. In citrus rough lemon rootstock is mostly used for raising the plants but due to its susceptibility to phytophthora it leads to the poor-quality fruits. Due to this the commercial growers are in a great loss (Nasir et al., 2011). In view of these facts the performance of Carrizo rootstock with sweet orange cultivars were undertaken under research study.

\section{Materials and Methods}

The research study was conducted at the experimental plot of Horticulture Department, Khalsa College, Amritsar during 2019-2020.

Selection of rootstock

One-year old seedlings of Carrizo which were procured were raised in greenhouse at the Fruit Research Station, Jallowal (Jalandhar). Equal sized, healthy and vigorous seedlings were selected for study.

\section{Selection of scion}

Current season shoots of sweet orange cvs. 'Blood Red', 'Jaffa' and 'Valencia Late' were used for collecting scion buds. The scion buds were healthy and disease free. They were collected during first week of February and July-October from college citrus block.

\section{Time of T-budding}

The scion buds were T-budded on to the rootstock at five different times (First weeks of February, July, August, September and October respectively). The T-budding operation was completed on same day of the budding.

\section{Execution of budding}

The budding was performed by the T-budding method. First a horizontal cut was made on the rootstock at around $10-15 \mathrm{~cm}$ above the ground level. Another vertical cut was made from the middle of the horizontal cut (making a T) and the flap of the bark was opened. After making the ' $T$ ' cut on stock, a boat shaped bud was taken from the scion and fixed in the T-cut flap and was tied with the polythene tape of 200 gauge. Utmost care was taken in the protection of the budded joint against infection. The budded plants were irrigated regularly. Record was taken into consideration days to sprouting, time for healing of bud union(days), plant height $(\mathrm{cm})$, number of branches and leaves buddling ${ }^{-1}$, leaf total nitrogen, phosphorous, potassium and root volume $\left(\mathrm{cm}^{3}\right)$ were recorded 120 days after budding.

\section{Experimental procedures}

Time to sprouting (days)

Time taken in days for initiation of sprouting were counted from the date of budding to the date of first sprouting for each treatment in each replication. 


\section{Survival percentage}

The number of survived budded plants was counted from all treatments in each replication and then calculated the percentages by following formula:

Survival percentage $=$ number of survived budded plants/total number of sprouted buds $\times 100$

\section{Time for healing of bud union (days)}

The number of days taken for complete healing of bud union after the date of T-budding was considered as the time for healing of bud union. The results were expressed in number of days.

Plant height $(\mathrm{cm})$

The data on height of the plant was recorded at 45, 60, 90 and 120 DAB (days after budding). Five plants were selected randomly within each replication. Plant height was measured with scale from the root zone to the top of the plant and was expressed as average per plant in centimeter $(\mathrm{cm})$.

\section{Number of leaves buddling -1}

Leaves were counted at45, 60, 90 and up to 120 days after T-budding. All the leaves, irrespective of their size, on the scion shoot were counted and mean number of leaves per plant was calculated and presented in the results.

\section{Leaf area $\left(\mathrm{cm}^{2}\right)$}

Average leaf area was calculated with the help of leaf area meter by taking 10 fully grown matured leaves in each replication after 120 days of T-budding.

\section{Leaf total nitrogen (\%)}

The total leaf nitrogen was calculated with Kjeldahl's method and the results obtained were expressed in percentage (Chapman and Parker, 1961).

\section{Leaf total phosphorous (\%)}

The total leaf phosphorous was determined by vanadomolybdo phosphoric yellow colour method and the results were expressed in percentage (Chapman and Parker, 1961).

\section{Leaf total potassium (\%)}

The potassium content in leaves was determined by flame photometric method and the results were presented in percentage (Chapman and Parker, 1961).

\section{Root length $(\mathrm{cm})$}

The length of the root was taken with the help of measuring scale at $120 \mathrm{DAB}$ and mean root length of five plants was calculated and expressed in centimeters (Chapman and Parker, 1961).

\section{$\underline{\text { Root volume }\left(\mathrm{cm}^{3}\right)}$}

The volume of the root was measured by dipping the roots in beaker (water displacement method). It was done in five randomly selected plants from each treatment in each replication 120 days after T-budding and then the average was calculated. The results were expressed in centimeter per cube (Chapman and Parker, 1961). 


\section{Statistical analysis}

The data recorded for each observed character under the study was subjected to Analysis of Variance (ANOVA) in the Department of Agricultural Statistics, Khalsa College, Amritsar as per the technique of Factorial Randomized Block Design (FRBD) using the software Elementary Designs Analysis (EDA). The critical difference $(C D)$ was used to assess the significance differences between the treatment means.

\section{Results and Discussion}

\section{Days to sprouting}

The data clearly depicted that out of the cultivars of sweet orange early sprouting was noticed in 'Blood Red' $\left(\mathrm{V}_{1}\right)$ accounting (28.30) days while the mean value of 'Valencia late' $\left(\mathrm{V}_{3}\right)$ showed a slight variation as compared to $\mathrm{V}_{1}$ with 29.27 days. Maximum number of days (31.78 days) were noted in 'Jaffa cultivar' $\left(\mathrm{V}_{2}\right)$. Less days taken for bud sprouting in the respective cultivar can be attributed to the successful budding union of stock and scion. Also 'Blood Red' species gave maximum sprouting percentage due to which days to sprouting was also reduced. The results of the present study support the findings of Ishfaq et al. (2012) and Rehman et al. (2017) in sweet orange and Verma et al. (2006) in grapes. As compared to the timings T-budding performed under $T_{3}$ - first week of September sprouted earlier in 26.46 days and budding of first week of February $\left(T_{5}\right)$ took maximum days (32.16 days) to sprout. Earliness in sprouting in the scions budded at different time intervals was observed as time progressed from February to September and then further a delay in sprouting was observed in October. Earliness might be due to the optimum temperature regime for conducting feasible cell activity at the union point which built early vascular connections between xylem and cambium tissue of the scion favouring the scion bud to sprout earlier (Hartmann et al., 2002). The earlier findings of Baloda et al. (2016) and Kaur and Kaur (2018) in jamun justify the present results. Among interactions of cultivars and budding intervals earlier sprouting in 24.62 days was noticed in Blood Red plants budded during the first week of September whereas, maximum days (34.13 days) were reported in Jaffa cultivar budded in the first week of February (Figure 1).

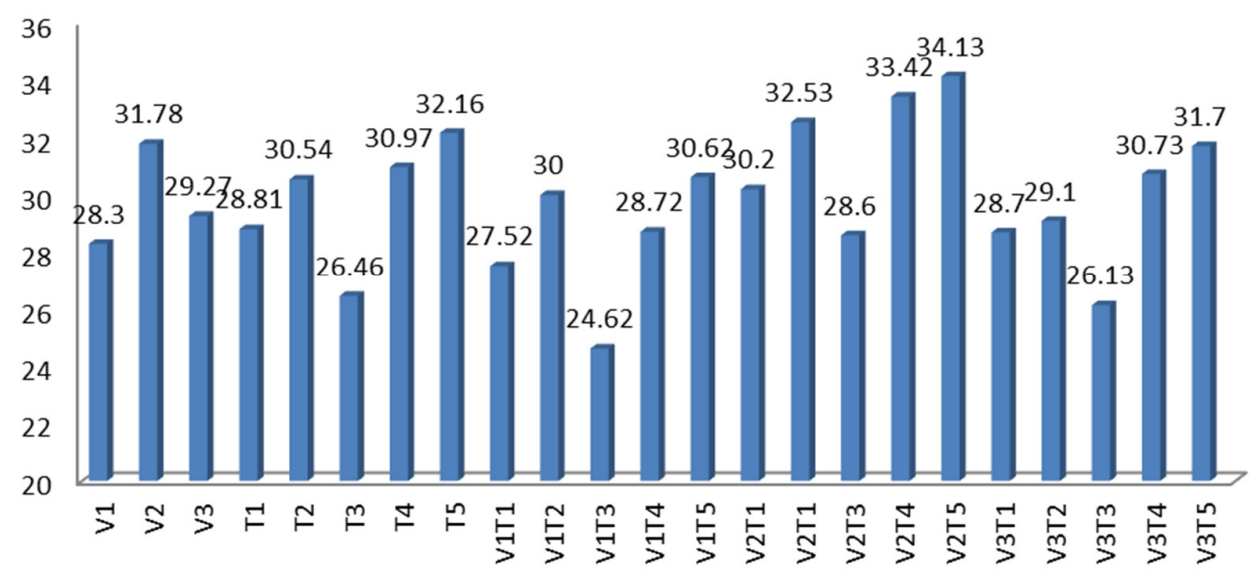

Figure 1. Response of sweet orange cultivars, time of T-budding and interactions on days to sprouting 


\section{Survival percentage}

The mean data regarding sweet orange cultivars showed that the maximum survival $(89.40 \%)$ was observed in 'Blood Red' cultivar $\left(\mathrm{V}_{1}\right)$ and minimum (83.42\%) in cultivar 'Jaffa' $\left(\mathrm{V}_{2}\right)$ (Figure 2). The variation observed in survival percentage of different sweet orange cultivars might be due to the fact that the rootstock had a better graft compatibility with certain sweet orange varieties under study (Rehman et al., 2017). Different times of T-budding also had a significant influence on survival percentage. It was observed that budding performed during the first week of September $\left(\mathrm{T}_{3}\right)$ had maximum survival percentage $(91.99 \%)$ with the minimum survival (83.88\%) observed when budding was done during first week of August $\left(T_{1}\right)$. The prevailing environmental conditions might be responsible for survival. The availability of sufficient sap from the scion and stock might have rapidly healed the bud union. Due to this the swollen bud acquired better growth. The findings of Gotur et al. (2017) in guava, Baloda et al. (2016) and Mahore (2014) jamun advocates the present findings. The interactive effect of cultivars and budding intervals registered maximum survival (94.57\%) in 'Blood Red' cultivar budded in the first week of September $\left(\mathrm{V}_{1} \mathrm{~T}_{3}\right)$ while the minimum survival 79.53 percentage was recorded when 'Jaffa' cultivar was budded during first week of August $\left(\mathrm{V}_{2} \mathrm{~T}_{1}\right)$ (Figure 3).

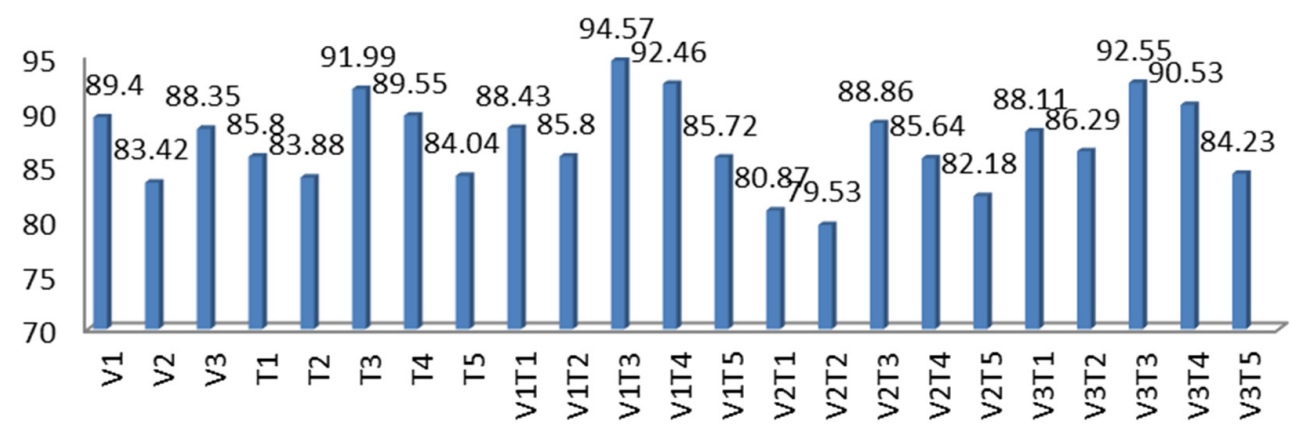

Figure 2. Response of different sweet orange cultivars, time of T-budding and interactions on survival percentage

\section{Time for healing of bud union (days)}

The data depicted that the time for healing of bud union was minimum (31.39 days) in 'Blood Red' cultivar $\left(V_{1}\right)$ where as it was maximum in Jaffa cultivar of sweet orange $\left(V_{2}\right)$ generating 34.56 days (Figure 4). Different times of T-budding operation also had a significant influence on the time for healing of bud union. It was observed that minimum time (29.14 days) for healing was taken when budding was done in the first week of September $\left(T_{3}\right)$ and the maximum time of 35.77 days was recorded when budding operation was performed during first week of February $\left(\mathrm{T}_{5}\right)$. Regarding the combined effect of cultivars and budding time 'Blood Red' cultivar budded during first week of September $\left(\mathrm{V}_{1} \mathrm{~T}_{3}\right)$ healed earlier in 8.26 days while the maximum time (35.83) days for healing of graft union was recorded when 'Jaffa' cultivar was budded during first week of February $\left(V_{2} T_{5}\right)$. The minimum time required by the combination $V_{1} T_{3}$ ('Blood Red' during first week of September) might have resulted from a closure alignment of cambial layer in stock and scion during that time which is conducive for the rapid formation of the bud union (Thokchom et al., 2019) (Figure 5). 


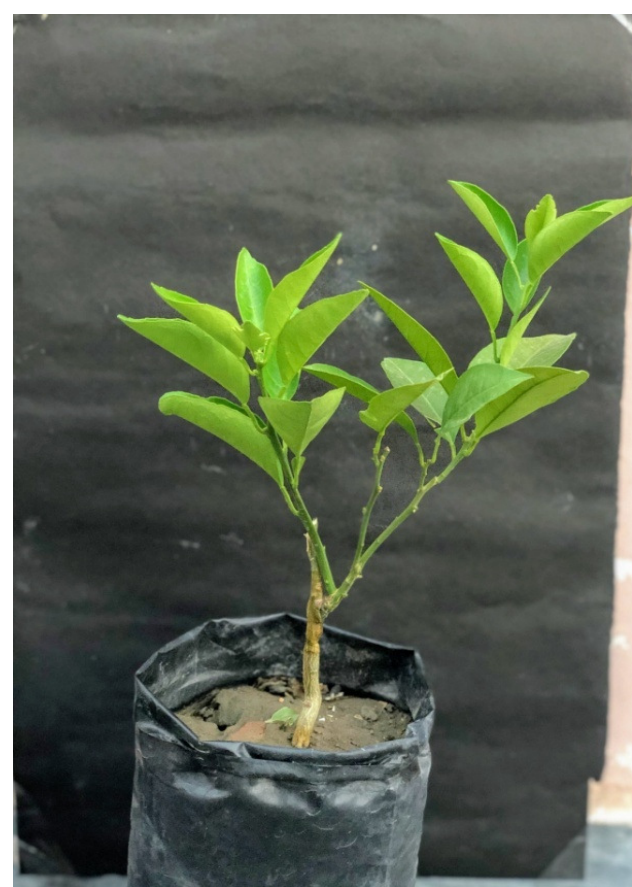

(a)

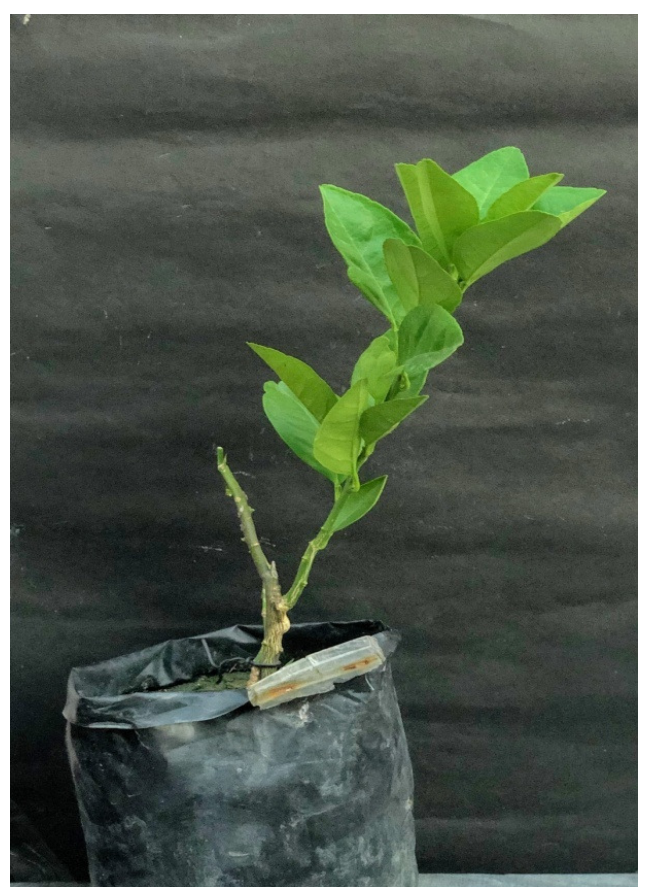

(b)

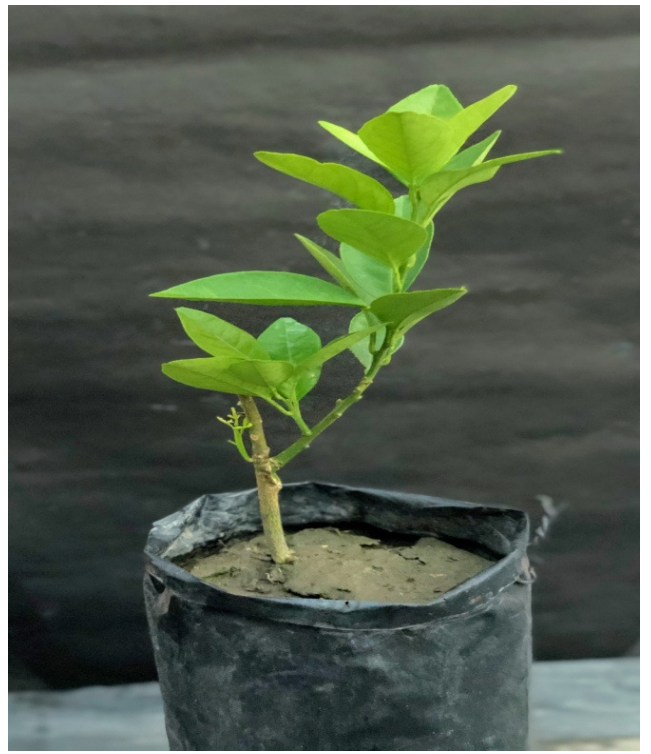

(c)

Figure 3. Survival of plants budded during first week of September at 120 days after budding in sweet orange cultivar (a) 'Blood Red' (b) 'Jaffa' (c) 'Valencia Late' 


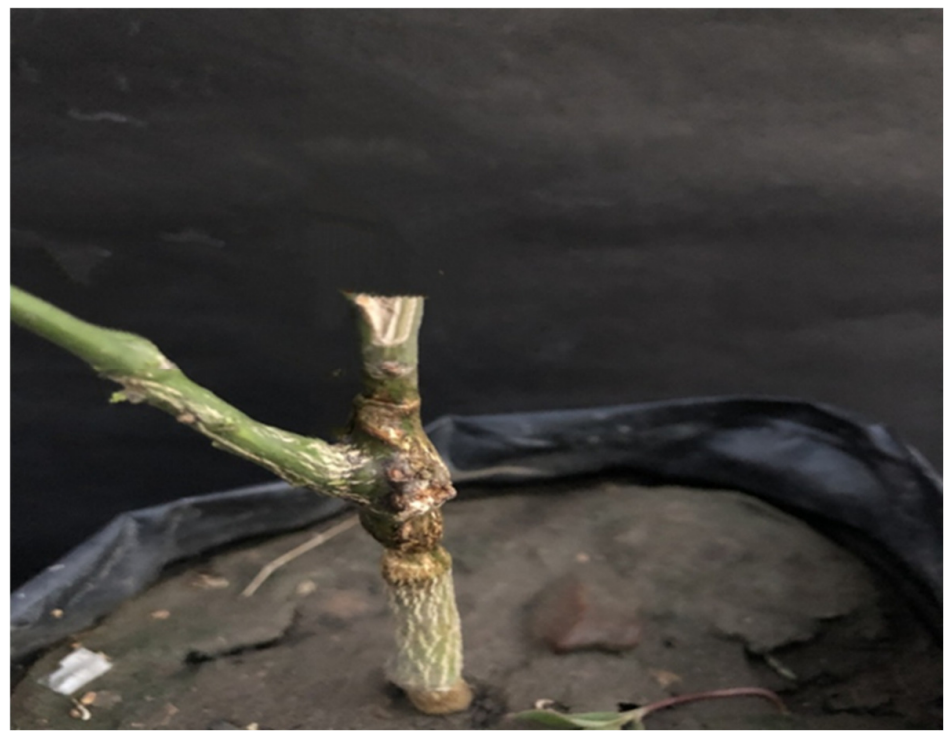

Figure 4. A view of healed bud union of sweet orange cv. 'Blood Red'

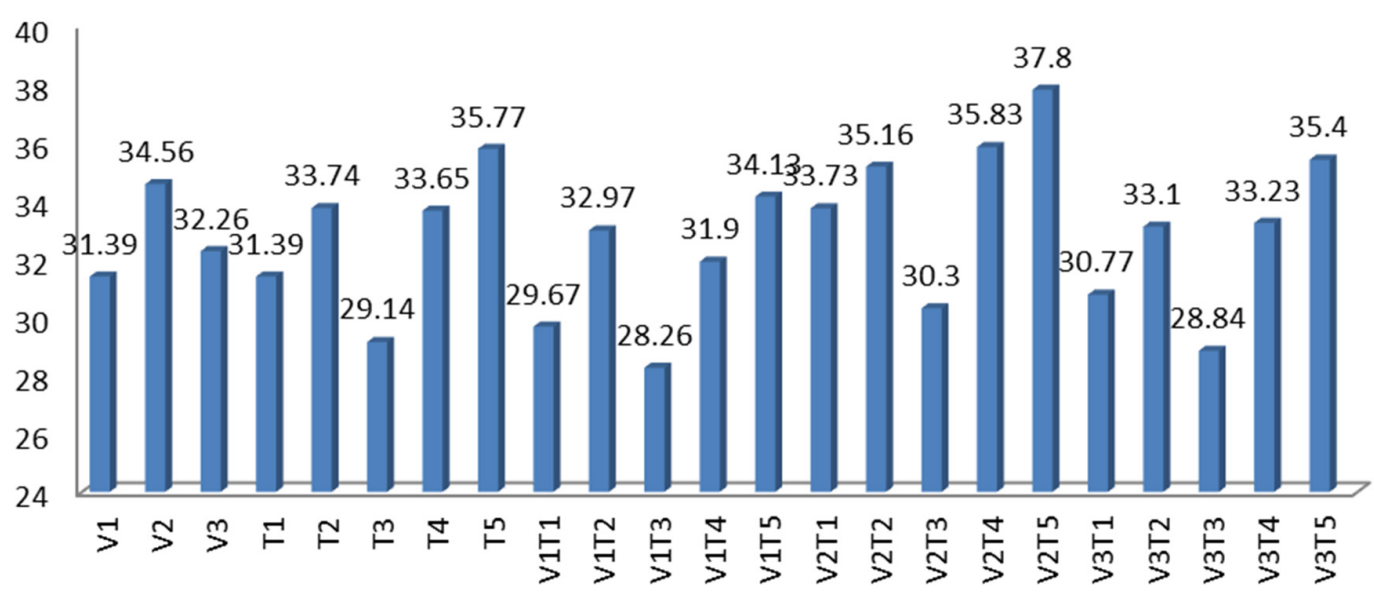

Figure 5. Response of different sweet orange cultivars, time of T-budding and interactions on time for healing of bud union

\section{Plant height $(\mathrm{cm})$}

From the results it has been found that 'Blood Red' $\left(\mathrm{V}_{1}\right)$ produced plants with significantly maximum height $(22.93 \mathrm{~cm})$ after 120 days of budding and the minimum $(20.16 \mathrm{~cm})$ plant height in $\mathrm{V}_{2}$ was recorded effectively throughout the growing period. An increase in plant height might be attributed to the vigorous character of scion. Another reason for the greater height of plants might be that the bud sprouted earlier received a fairly long period of favorable weather for vegetative growth (Singh, 2007). It was evident from the results obtained by Ahmed et al. (2013) that the cultivar and rootstock combination affected the plant height. Among different times of T-budding the first week of September $\left(\mathrm{T}_{3}\right)$ budded plants were $(23.04 \mathrm{~cm})$ long and when budding was practiced during first week of August $\left(\mathrm{T}_{2}\right)$ the plants remained at the lowest height $(21.11$ $\mathrm{cm})$ at $120 \mathrm{DAB}$. The research trial carried out by Patel et al. (2007) wherein they observed that plant height was influenced by date of propagation. The higher content of auxins in the plants (Hartmann et al., 2007) was also responsible for plant height. A perusal of data revealed that the interactions between sweet orange cultivars and time of T-budding were found to be non significant at the early stages but the results after $60 \mathrm{DAB}$ showed significant results with maximum plant height $(24.75 \mathrm{~cm})$ in sweet orange cv. Blood Red cultivar budded in 
first week of September- $V_{1} T_{3}$ which was statistically superior over all the other treatment combinations, whereas minimum plant height $(19.23 \mathrm{~cm})$ was noted down in Jaffa cultivar when budding was performed during first week of February $\left(V_{2} T_{5}\right)$. However, the lowest height was observed in $V_{2} T_{5}$ measuring $15.26 \mathrm{~cm}$.

\section{Number of branches buddling ${ }^{-1}$}

It is evident from the data that maximum number of branches were produced in 'Blood Red' cultivar $\left(V_{1}\right)$ accounting to 1.14 at $120 \mathrm{DAB}$ where as they were found to be minimum (1.02) at $120 \mathrm{DAB}$ in 'Jaffa' cultivar $\left(\mathrm{V}_{2}\right)$. The reason might be due to the maximum quantity of leaves buddling ${ }^{-1}$ and longest shoot length recorded in the citrus species. These results are in close agreement to the findings of Khattak (1990) who recorded significant variation in the branch quantity of the citrus varieties propagated by budding. Rehman et al. (2017) also reported the same in sweet orange. Among different times all the intervals registered slight variations. In the results maximum number of branches (1.15) were obtained in first week of September $\left(\mathrm{T}_{3}\right)$ budded plants whereas the minimum (1.02) branches were obtained when budding was performed during first week of August $\left(T_{2}\right)$ after $120 \mathrm{DAB}$. This might be due to the good vegetative growth of the buddling as a result of favourable environmental conditions leading to an increase in number of branches of buddling. It corresponds to the findings of Khan et al. (2018) wherein it was observed that time of propagation had a significant effect on number of branches buddling ${ }^{-1}$. It is evident from the tables that non significant interactions were noticed between the sweet orange cultivars and time of T-budding.

\section{Leaf number buddling ${ }^{-1}$}

Maximum leaves (21.62) were registered in 'Blood Red' cultivar $\left(\mathrm{V}_{1}\right)$ while the minimum leaves (18.26) were observed in cultivar 'Jaffa' at $120 \mathrm{DAB}$. It might be due to the maximum buddling girth and compatibility of these two species. The healthier buddings resulted in maximum number of leaves (Rehman et al., 2017). Similar results were found by Rehman and Rab (2012) wherein the analysis of variance showed that cultivar and rootstock combination had a significant effect on the number of leaves per buddling. Pomper et al. (2009) also viewed that different scion cultivars have an efficient influence on number of leaves of sweet orange cultivars. The data about different timings of T-budding also showed significant effects on the number of leaves. Among different times of budding, first week of September $\left(T_{3}\right)$ was found to be statistically superior in increasing the number of leaves to the tune of 21.64 and minimum number of leaves (18.84) were produced per buddling budded during first week of August $\left(\mathrm{T}_{2}\right)$. Increment in leaves can be due to good growth in linear and radial plant growth as an effect of the adaptable atmospheric conditions leading to instant dividing cells (Chauhan, 2000). Also, the cell activity and better healing of graft union during these months have increased leaf formation. The findings align with Singh et al. (2004) in citrus. Interactive effect of cultivars and propagation significantly influenced the leaf number being the maximum number of leaves (22.86) were recorded in treatment combination $\mathrm{V}_{1} \mathrm{~T}_{3}$ and $\mathrm{V}_{3} \mathrm{~T}_{4}$ being minimum (22.40) at $120 \mathrm{DAB}$.

\section{Leaf total nitrogen (\%)}

The data furnished clearly depicted that sweet orange cultivars and time of T-budding along with their interaction had significant influence over the total leaf nitrogen. Among the sweet orange cultivars 'Blood Red' $\left(V_{1}\right)$ showed maximum leaf total nitrogen $(1.89 \%)$ content while the mean value of 'Valencia Late' $\left(V_{3}\right)$ showed a slight variation as compared to $\mathrm{V}_{1}$ with $1.81 \%$. Minimum leaf nitrogen $(1.54 \%)$ was noted in 'Jaffa' cultivar $\left(\mathrm{V}_{2}\right)$ analysed $120 \mathrm{DAB}$. It might be due to the reason that the scion influences the root system of the rootstock which in turn influences the nutrient uptake by the plants (Goswami, 2017). Toplu et al. (2008) also stated that the highest total $\mathrm{N}$ concentration was observed in scion leaves of 'Valencia Late' variety on Carrizo. The results are also in correspondence with the findings of Perez-Zamora (2004) and Jahromi et al. (2012). As compared to the budding period the first week of September $\left(T_{3}\right)$ resulted in maximum leaf total nitrogen (1.96\%) followed by $T_{4}$ with $1.84 \%$ leaf total nitrogen. The leaf total nitrogen in $T_{1}$ and $T_{2}$ showed slight variations while budding performed in first week of February $\left(T_{5}\right)$ resulted in minimum total leaf nitrogen 
(1.58\%) 120 DAB. The content of nitrogen (2.15\%) was maximum from the 'Blood Red' plants when they were budded in the first week of September and was minimum (1.43\%) when 'Jaffa' cultivar was budded in first week of February which was at par with the leaf total nitrogen recorded in plants budded with Jaffa cultivar during first week of August (1.44\%) and July (1.48\%) (Figure 6).

\section{Leaf total phosphorous (\%)}

It was evident from the data that non significant influence on the leaf total phosphorus in various stionic combinations was recorded after 120 days of budding. However, among various cultivars and times of $\mathrm{T}$ budding $\mathrm{V}_{1}$ and $\mathrm{T}_{3}$ showed a comparatively higher leaf total phosphorus i.e. $0.07 \%$ and $0.08 \%$ respectively while among various treatment combinations, the highest leaf total phosphorus i.e. $0.09 \%$ was observed in $V_{1} T_{3}$, $\mathrm{V}_{1} \mathrm{~T}_{4}$ and $\mathrm{V}_{3} \mathrm{~T}_{3}$ and minimum $(0.02 \%)$ was observed in $\mathrm{V}_{2} \mathrm{~T}_{5}$ treatment (Figure 6).

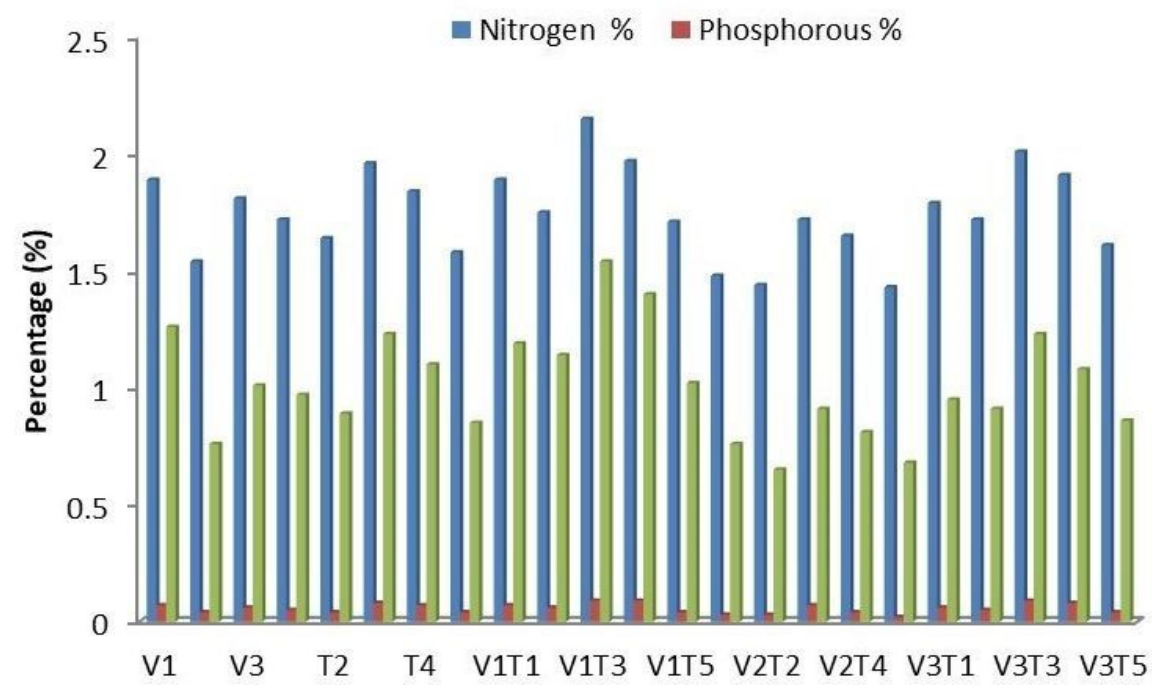

Figure 6. Response of sweet orange cultivars, time of T-budding and interactions on plant nutrient status

\section{Leaf total potassium (\%)}

The data presented in Table 2 clearly depicted that sweet orange cultivars and time of T-budding along with their interaction had significant influence over the total leaf potassium. It is evident from the data that 'Blood Red' $\left(\mathrm{V}_{1}\right)$ resulted in maximum leaf total potassium (1.26\%) while the mean value of 'Valencia Late' $\left(\mathrm{V}_{3}\right)$ showed a slight variation as compared to $\mathrm{V}_{1}$ with $1.01 \%$. Minimum leaf potassium $(0.76 \%)$ was noted in 'Jaffa'. Sau et al. (2018) also stated that the highest total K concentration was observed in scion leaves of Nagpur mandarin on Karna Khatta. Jahromi et al. (2012) also confirmed the same. As compared to the budding the first week of September $\left(\mathrm{T}_{3}\right)$ resulted in maximum leaf total potassium $(1.23 \%)$ followed by $\mathrm{T}_{4}$ with $1.10 \%$ leaf total potassium. The leaf total potassium in $T_{1}$ and $T_{2}$ showed slight variations while budding performed in first week of February $\left(T_{5}\right)$ resulted in minimum total leaf potassium $(0.85 \%)$. Regarding interactions maximum potassium (1.54\%) was in 'Blood Red' when budded on the first week of September. 
Table 1. Effect of sweet orange cultivars and time of budding on sprouting and buddling vigour

\begin{tabular}{|c|c|c|c|c|c|}
\hline $\begin{array}{c}\text { Factor A } \\
\text { (Cultivars) }\end{array}$ & $\begin{array}{c}\text { Days to } \\
\text { sprouting }\end{array}$ & $\begin{array}{l}\text { Time for healing } \\
\text { bud union } \\
\text { (days) }\end{array}$ & $\begin{array}{c}\text { Survival } \\
(\%)\end{array}$ & $\begin{array}{l}\text { Plant } \\
\text { height } \\
(\mathrm{cm})\end{array}$ & $\begin{array}{c}\text { Number of } \\
\text { branches } \\
\text { plant }^{-1}\end{array}$ \\
\hline V1 & 28.30 & 31.39 & 89.40 & 22.93 & 1.14 \\
\hline $\mathrm{V} 2$ & 31.78 & 34.56 & 83.42 & 20.16 & 1.02 \\
\hline V3 & 29.27 & 32.26 & 88.35 & 22.22 & 1.07 \\
\hline $\mathrm{CD}(\mathrm{p}=0.05)$ & 0.30 & 0.31 & 0.30 & 0.17 & 0.03 \\
\hline \multicolumn{6}{|l|}{ Factor B (Time) } \\
\hline $\mathrm{T} 1$ & 28.81 & 31.39 & 85.80 & 21.22 & 1.09 \\
\hline $\mathrm{T} 2$ & 30.54 & 33.74 & 83.88 & 20.65 & 1.02 \\
\hline T3 & 26.46 & 29.14 & 91.99 & 23.04 & 1.15 \\
\hline T4 & 30.97 & 33.65 & 89.55 & 22.84 & 1.09 \\
\hline $\mathrm{T5}$ & 32.16 & 35.77 & 84.04 & 21.11 & 1.03 \\
\hline $\mathrm{CD}(\mathrm{p}=0.05)$ & 0.39 & 0.39 & 0.39 & 0.23 & 0.04 \\
\hline \multicolumn{6}{|c|}{ Interaction $(\mathrm{A} \times \mathrm{B})$} \\
\hline V1T1 & 27.52 & 29.67 & 88.43 & 22.30 & 1.15 \\
\hline V1T2 & 30 & 32.97 & 85.80 & 21.40 & 1.07 \\
\hline V1T3 & 24.62 & 28.26 & 94.57 & 24.75 & 1.25 \\
\hline V1T4 & 28.72 & 31.90 & 92.46 & 24.09 & 1.20 \\
\hline V1T5 & 30.62 & 34.13 & 85.72 & 22.15 & 1.07 \\
\hline V2T1 & 30.2 & 33.73 & 80.87 & 19.68 & 1.03 \\
\hline V2T2 & 32.53 & 35.16 & 79.53 & 19.53 & 0.97 \\
\hline V2T3 & 28.6 & 30.30 & 88.86 & 21.45 & 1.07 \\
\hline V2T4 & 33.42 & 35.83 & 85.64 & 20.91 & 1.01 \\
\hline $\mathrm{V} 2 \mathrm{~T} 5$ & 34.13 & 37.80 & 82.18 & 19.23 & 1.01 \\
\hline V3T1 & 28.7 & 30.77 & 88.11 & 21.70 & 1.11 \\
\hline V3T2 & 29.1 & 33.10 & 86.29 & 21.01 & 1.02 \\
\hline V3T3 & 26.13 & 28.84 & 92.55 & 22.93 & 1.15 \\
\hline V3T4 & 30.73 & 33.23 & 90.53 & 23.51 & 1.07 \\
\hline V3T5 & 31.7 & 35.40 & 84.23 & 21.94 & 1.02 \\
\hline $\mathrm{CD}(\mathrm{p}=0.05)$ & 0.67 & 0.69 & 0.69 & 0.40 & NS \\
\hline
\end{tabular}

$\mathrm{V}_{1}=$ Blood red, $\mathrm{V}_{2}=$ Jaffa, $\mathrm{V}_{3}=$ Valencia late $\mathrm{T}_{1}=$ First week of July, $\mathrm{T}_{2}=$ First week of August, $\mathrm{T}_{3}=$ First week of September, $T_{4}=$ First week of October, $T_{5}=$ First week of February

\section{Root volume $\left(\mathrm{cm}^{3}\right)$}

Under the research study the sweet orange cultivars and time of T-budding on root volume was studied at 120 days after budding and results so obtained are depicted in Table 2. Results of the study showed that root volume varied significantly in different sweet orange cultivars. The maximum root volume $\left(6.50 \mathrm{~cm}^{3}\right)$ was given by the 'Blood Red'/Carrizo combination which was followed by cultivar 'Valencia Late' with $\left(5.23 \mathrm{~cm}^{3}\right)$ and the minimum root volume $\left(4.52 \mathrm{~cm}^{3}\right)$ was observed in the plants budded with 'Jaffa' cultivar $\left(\mathrm{V}_{2}\right)$. The increased volume of rootstock might be improved by the soil growth of plants of sweet orange varieties. The reason might also be the better stock-scion compatibility used in the study. Similar results had been stated by Girardi and Filho (2006) who worked on different sweet orange varieties and found significant effect on root growth and volume of the plants. The data about different times of budding also showed significant influence on root volume. Maximum root volume $\left(5.98 \mathrm{~cm}^{3}\right)$ was observed when budding operation was performed in the first week of September which was at par with budding operation performed during first week of October with $5.85 \mathrm{~cm}^{3}$ and the minimum root volume $\left(4.67 \mathrm{~cm}^{3}\right)$ was recorded in the plants budded during the first week of July $\left(T_{1}\right)$. Interactions between cultivars and time of budding also significantly influenced the root volume. Roots with maximum volume $\left(7.15 \mathrm{~cm}^{3}\right)$ were produced in $\mathrm{V}_{1} \mathrm{~T}_{3}$ treatment combination while the minimum root volume $\left(3.52 \mathrm{~cm}^{3}\right)$ was recorded in the treatment combination of $V_{2} T_{1}$. 
Table 2. Effect of sweet orange cultivars and time of budding on buddling leaf and root parameters

\begin{tabular}{|c|c|c|c|c|c|}
\hline $\begin{array}{c}\text { Factor A } \\
\text { (Cultivars) }\end{array}$ & $\begin{array}{c}\text { Number } \\
\text { of } \\
\text { leaves }\end{array}$ & $\begin{array}{c}\text { Leaf total } \\
\text { nitrogen } \\
(\%)\end{array}$ & $\begin{array}{l}\text { Leaf total } \\
\text { phosphorous } \\
(\%)\end{array}$ & $\begin{array}{l}\text { Leaf total } \\
\text { potassium } \\
(\%)\end{array}$ & $\begin{array}{c}\text { Root } \\
\text { volume } \\
\left(\mathrm{cm}^{3}\right)\end{array}$ \\
\hline V1 & 21.62 & 1.89 & 0.07 & 1.26 & 6.50 \\
\hline V2 & 18.26 & 1.54 & 0.04 & 0.76 & 4.52 \\
\hline V3 & 21.59 & 1.81 & 0.06 & 1.01 & 5.23 \\
\hline $\mathrm{CD}(\mathrm{p}=0.05)$ & 0.21 & 0.02 & NS & 0.02 & 0.18 \\
\hline \multicolumn{6}{|l|}{ Factor B (Time) } \\
\hline T1 & 19.94 & 1.72 & 0.05 & 0.97 & 4.67 \\
\hline $\mathrm{T} 2$ & 18.84 & 1.64 & 0.04 & 0.89 & 5.02 \\
\hline T3 & 21.64 & 1.96 & 0.08 & 1.23 & 5.98 \\
\hline $\mathrm{T} 4$ & 21.09 & 1.84 & 0.07 & 1.10 & 5.85 \\
\hline T5 & 20.94 & 1.58 & 0.04 & 0.85 & 5.55 \\
\hline $\mathrm{CD}(\mathrm{p}=0.05)$ & 0.28 & 0.03 & NS & 0.03 & 0.24 \\
\hline \multicolumn{6}{|l|}{ Interaction $(\mathrm{A} \times \mathrm{B})$} \\
\hline V1T1 & 21.40 & 1.89 & 0.07 & 1.19 & 5.92 \\
\hline V1T2 & 19.39 & 1.75 & 0.06 & 1.14 & 6.38 \\
\hline V1T3 & 22.86 & 2.15 & 0.09 & 1.54 & 7.15 \\
\hline V1T4 & 22.78 & 1.97 & 0.09 & 1.40 & 6.92 \\
\hline V1T5 & 21.54 & 1.71 & 0.04 & 1.02 & 6.12 \\
\hline V2T1 & 17.50 & 1.48 & 0.03 & 0.76 & 3.52 \\
\hline V2T2 & 17.06 & 1.44 & 0.03 & 0.65 & 3.87 \\
\hline V2T3 & 19.56 & 1.72 & 0.07 & 0.91 & 5.03 \\
\hline V2T4 & 18.01 & 1.65 & 0.04 & 0.81 & 5.21 \\
\hline $\mathrm{V} 2 \mathrm{T5}$ & 19.08 & 1.43 & 0.02 & 0.68 & 4.97 \\
\hline V3T1 & 20.91 & 1.79 & 0.06 & 0.95 & 4.59 \\
\hline V3T2 & 20.09 & 1.72 & 0.05 & 0.91 & 4.81 \\
\hline V3T3 & 22.49 & 2.01 & 0.09 & 1.23 & 5.76 \\
\hline V3T4 & 22.40 & 1.91 & 0.08 & 1.08 & 5.41 \\
\hline V3T5 & 22.22 & 1.61 & 0.04 & 0.86 & 5.26 \\
\hline $\mathrm{CD}(\mathrm{p}=0.05)$ & 0.49 & 0.05 & NS & 0.05 & 0.41 \\
\hline
\end{tabular}

$\mathrm{V}_{1}=$ Blood red, $\mathrm{V}_{2}=$ Jaffa, $\mathrm{V}_{3}=$ Valencia late $\mathrm{T}_{1}=$ First week of July, $\mathrm{T}_{2}=$ First week of August, $\mathrm{T}_{3}=$ First week of September, $\mathrm{T}_{4}=$ First week of October, $\mathrm{T}_{5}=$ First week of February

\section{Conclusions}

As an outcome of the research study T- budding of sweet orange cultivar 'Blood Red' on Carrizo rootstock in the first week of September was successful than other cultivars under the agro-climatic conditions of Punjab in terms of budding success and vegetative growth of the buddings so formed. This will ensure better germplasm for successful cultivation of sweet orange leading to a good income to the commercial fruit growers.

\section{Authors' Contributions}

Conceptualization of research work and designing of experiment (AJK); Execution of field/lab experiments and data collection (FDS); Analysis of data and interpretation (FDS and AJK); Preparation of manuscript (AJK). Both authors read and approved the final manuscript. 


\section{Acknowledgements}

Heartiest thanks to Khalsa College Charitable Society for supporting the research.

\section{Conflict of Interests}

The authors declare that there are no conflicts of interest related to this article.

\section{References}

Ahmed MJ, Gillani MJS, Kiani FA (2013). Response of apple (Malus domestica Borkh.) cultivars grafted on two rootstocks under sub-humid temperate climate of Azad Jammu and Kashmir. Pakistan Journal of Agricultural Sciences 50:379-86.

Baloda S, Sharma JR, Singh S, Bishnoi C (2016). Effect of time of budding in Jamun (Syzygium cumini) under different growing conditions. International Journal of Agricultural Sciences 8:1923-1925.

Chahal TS, Gill PPS [2015]. Performance of exotic sweet orange cultivars on different rootstocks under north western India. Indian Journal of Science and Technology 8:59391-92.

Girardi EA, Filho FAAM (2006). Production of inter stocked 'Pera' sweet orange nursery trees on 'Volkamer' lemon and 'Swingle' citrumelo rootstocks. Scientia Agricola 63(1):5-10. http://dx.doi.Org/10.1590/S010390162006000100002

Goswami A, Srivastav M, Sharma RR, Nagraja A (2017). Scion-stock interactions in fruit crops. https://www.biotecharticles.com/Agriculture-Article/Scion-Stock-Interactions-in-Fruit-Crops-3888.html

Gotur M, Sharma DK, Chawla SL, Joshi CJ, Navya K (2017). Performance of wedge grafting in guava (Psidium guajava L.) under different growing conditions. Plant Archives 17:1283-1287.

Hartmann HT, Kester DE, Davis JFT, Robert LG (2002). Techniques of grafting. In: Plant Propagation: Principles and Practices (6 $6^{\text {th }}$ edition). Prentice Hall Pvt. Ltd., New Delhi, pp 772-780.

Hartmann HT, Kester DE, Davies JFT, Robert LG (2007). Plant Propagation: Principles and Practices. $7^{\text {th }}$ edition, Prentice-Hall of India Pvt. Ltd. New Delhi, pp 199-248.

Jahromi AA, Hasanzada H, Farahi MH (2012). Effect of rootstock type and scion cultivar on citrus leaf total nitrogen. World Applied Sciences Journal 19:140-143. https://dx.doi.org/10.5829/idosi.wasj.2012.19.01.1192

Khan MR, Ghani F, Bostan N, Nabi G, Haji H, Ali A, Amin Jand Khalid S (2018). The influence of timing and position of scion on graft take success of lemon. Bolan Society for Pure and Applied Biology 7:330-337. http://dx.doi.org/10.19045.2018.70040

Khattak MAK (1990). Effect of different rootstocks and dates of budding on bud take success and rate of growth in kinnow mandarin. Plant Propagation. NAUP Hort Science 45:523-533.

Mahore (2014). Standardization of propagation method in Jamun. M.Sc. thesis Jawaharlal Nehru Vishwa Vidyalaya, Jabalpur.

Milind P, Chaturvedi D (2012). Orange: Range of benefits. International Research Journal of Pharmacy 3:59-63.

Patel R, Babu DK, Singh A, Yadav DS, De LC (2007). Soft wood grafting in mandarin (C. reticulata Blanco): a novel vegetative propagation technique. International Journal of Fruit Science 7:31-41. http://doi.org./10.1080/1553836100367673

Perez-Zamora O (2004). Leaf nutrient concentration, yield, production efficiency, juice quality and nutrimental indexes on Valencia orange grafted citrus rootstocks. Agrociencia 38:141-154.

Rehman M, Rab A (2012). Performance of citrus rootstocks in different potting media under screen house conditions. M.Sc. thesis, University of Agriculture Peshawar.

Rehman ZU, Sajid M, Naeem N, Nabi G, Khan A, Awan AA, Dawan KM (2017). Response of Australia sweet orange varieties on citrus rootstock under agro-climatic conditions of Peshawar. FUUAST Journal of Biology 7:241-251.

Sau S, Ghosh SN, Sarkar S, Gantail S (2018). Effect of rootstocks on growth, yield, quality, and leaf mineral composition of Nagpur mandarin (Citrus reticulata Blanco) grown in red lateritic soil of West Bengal, India. Scientia Horticulturae 237:142-147. 
Singh R, Dhaliwal HS, Rattanpal HS (2004). Effect of time of budding and growing conditions on bud success and growth of buddings of Kinnow mandarin. Journal of Research Punja Agricultural University 41:441-453.

Singh R (2007). Standardization of height and time of wedge grafting in mango (Mangifera indica L.) under western U.P. condition. Thesis submitted for the degree of PhD (Hort) S.V.P.U.A and T. Meerut- 250110 (UP).

Toplu C, Kaplankiran M, Demirkeser TH, Yildiz E (2008). The effects of citrus rootstocks on Valencia late and Rhode red Valencia oranges for some plant nutrient elements. African Journal of Biotechnology 7:4441-4445.

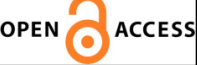

(c) (1)
The journal offers free, immediate, and unrestricted access to peer-reviewed research and scholarly work. Users are allowed to read, download, copy, distribute, print, search, or link to the full texts of the articles, or use them for any other lawful purpose, without asking prior permission from the publisher or the author.

License - Articles published in Notulae Scientia Biologicae are Open-Access, distributed under the terms and conditions of the Creative Commons Attribution (CC BY 4.0) License.

(c) Articles by the authors; SHST, Cluj-Napoca, Romania. The journal allows the author(s) to hold the copyright/to retain publishing rights without restriction. 